\title{
PUBLIC TRUST DAN PROFESI BK BERMARTABAT MENUJU KARAKTER KONSELOR YANG DIBUTUHKAN
}

\author{
Budi Suryono*
}

\begin{abstract}
Abstrak
Dunia globalisasi yang semakin berkembang pesat menyebabkan masyarakat disibukkan dengan rutinitas pekerjaan dan kariernya, bekerja dibawah tekanan dan kecemasan akan kesuksesan dalam kariernya, meninggalkan keluarga yang membutuhkan perhatian lebih dan kasih sayang. Kecenderungan kriminalitas meningkat dan kenakalan remaja serta perbuatan-perbuatan yang melampaui norma-norma sosial semakin subur. Sikap individualitas muncul. Begitulah dunia globalisasi saat ini, sehingga keberadaan konselor, psikolog dan pskiater sesungguhnya sangat dibutuhkan dan mempunyai peranan penting di dalam masyarakat industri seperti sekarang ini. Kehadiran konselor sepertinya menjawab tantangan zaman dan seiring dengan pesatnya kemajuan pasar global. Kualifikasi yang harus dimiliki seorang konselor adalah (1) memiliki nilai, sikap. ketrampilan, pengetahuan, dan wawasan dalam bidang profesi bimbingan dan konseling, dan (2) memperoleh pengakuan atas kemampuan dan kewenangan sebagai konselor.
\end{abstract}

Kata kunci : public trust, karakter konselor

* Budi Suryono adalah Dosen Program Studi Bimbingan dan Konseling Fakultas Ilmu Pendidikan IKIP PGRI Madiun 
Pendahuluan

Keberadaan konselor dalam sistem pendidikan nasional dinyatakan sebagai salah satu kualifikasi pendidik, sejajar dengan kualifikasi guru, dosen, pamong belajar, tutor, widyaiswara, fasilitator, dan instruktur (UU No. 20 Tahun 2003 Pasal 1 Ayat 6). Masingmasing kualifikasi pendidik, termasuk konselor, memiliki keunikan konteks tugas dan ekspektasi kinerja. Standar kualifikasi akademik dan kompetensi konselor dikembangkan dan dirumuskan atas dasar kerangka pikir yang menegaskan konteks tugas dan ekspektasi kinerja konselor. Sosok utuh kompetensi konselor mencakup kompetensi akademik dan profesional sebagai satu keutuhan. Kompetensi akademik merupakan landasan bagi pengembangan kompetensi profesional, yang meliputi: (1) memahami secara mendalam konseli yang dilayani, (2) menguasai landasan dan kerangka teoretik bimbingan dan konseling, (3) menyelenggarakan pelayanan bimbingan dan konseling yang memandirikan, dan mengembangkan pribadi dan profesionalitas konselor secara berkelanjutan

Untuk menjadi profesional seseorang harus menguasai dan memenuhi ketiga komponen yaitu: Komponen dasar keilmuan memberikan landasan bagi calon tenaga profesional dalam wawasan, pengetahuan, keterampilan, nilai dan sikap berkenaan dengan profesi yang dimaksud. Komponen substansi profesi membekali calon profesional apa yang menjadi fokus dan objek praktis spesifik pekerjaan profesionalnya. Komponen praktik mengarahkan calon tenaga profesional untuk menyelenggarakan praktik profesinya itu kepada sasaran pelayanan atau pelanggan secara tepat dan berdaya guna.

\section{Pembahasan}

1. Kualifikasi

Profesional

Konselor

Kualifikasi yang harus dimiliki seorang konselor (1) Memiliki nilai, sikap. ketrampilan, pengetahuan, dan wawasan dalam bidang profesi bimbingan dan konseling, yang 
menyangkut (a) Konselor wajib terus-menerus berusaha mengembangkan dan menguasai dirinya, (b) Konselor wajib memperlihatkan sifat-sifat sederhana, rendah hati, sabar, menepati janji, dapat dipercaya, jujur, tertib, dan hormat, (c) Konselor wajib memiliki rasa tanggung jawab terhadap saran ataupun peringatan yang diberikan kepadanya, khususnya dari rekan seprofesi yang berhubungan dengan pelaksanaan ketentuan tingkah laku profesional, (d) Konselor wajib mengusahakan mutu kerja yang tinggi dan tidak mengutamakan kepentingan pribadi termasuk material, finansial, dan popularitas, dan (e) Konselor wajib trampil dalam menggunakan teknik dan prosedur khusus dengan wawasan luas dan kaidah-kaidah ilmiah. (2) Memperoleh pengakuan atas kemampuan dan kewenangan sebagai konselor, yang meliputi (a) Pengakuan keahlian, dan (b) Kewenangan oleh organisasi profesi atas dasar wewenang yang diberikan kepadanya.

Objek praktis spesifik yang menjadi fokus pelayanan konseling adalah kehidupan efektif sehari-hari (KES). Dalam hal ini, sasaran pelayanan konseling adalah kondisi KES yang dikehendaki untuk dikembangkan dan kondisi kehidupan efektif sehari-hari yang terganggu (KES-T). Dengan demikian, pelayanan konseling pada dasarnya adalah upaya pelayanan dalam pengembangan KES dan penanganan KES-T.

Berkenaan dengan pendekatan dan teknologi, pengelolaan dan evaluasi pelayan konseling, Guru Bimbingan dan Konseling/Konselor wajib menguasai berbagai jenis layanan dan kegiatan pendukungnya dengan landasan teori, acuan praksis, standar prosedur operasional (SPO), serta implementasinya dalam praktik konseling. Pendekatan dan teknologi, pengelolaan dan evaluasi pelayanan itu perlu 
didukung oleh kaidah-kaidah

keilmuan dan teknologi seperti

psikologi, sosiologi, teknologiinformasi-komunikasi sebagai "alat" untuk lebih menepatgunakan dan mendayagunakan pelayanan konseling.

Mutu pelayanan konseling diukur dari penampilan paktik pelayanan oleh Guru Bimbingan dan Konseling /Konselor terhadap sasaran pelayanan. Penguasaan atas materi ketiga komponen trilogi profesi konseling tersebut diperolah dari studi pada program bidang konseling tingkat sarjana (S-1) ditambah dengan pendidikan profesi Guru Bimbingan dan Konseling /Konselor (PPK). Seluruh materi tersebut dipadukan dalam bentuk praktik pelayanan konseling melalui persiapan yang matang berupa berbagai program pelayanan sesuai dengan kebutuhan sasaran pelayanan.

\section{Problematika}

Kebermartabatan

Profesi

\section{Konseling}

Problematika muncul manakala terjadi kesenjangan antara apa yang dikehendaki dengan apa yang terjadi. Dalam praktik profesional konseling dewasa ini baik di setting sekolah maupun luar sekolah agaknya telah terjadi beberapa kesenjangan yang dapat diidentifikasikan dalam uraian berikut ini.

1. Belum standarnya istilah profesional yang dipakai

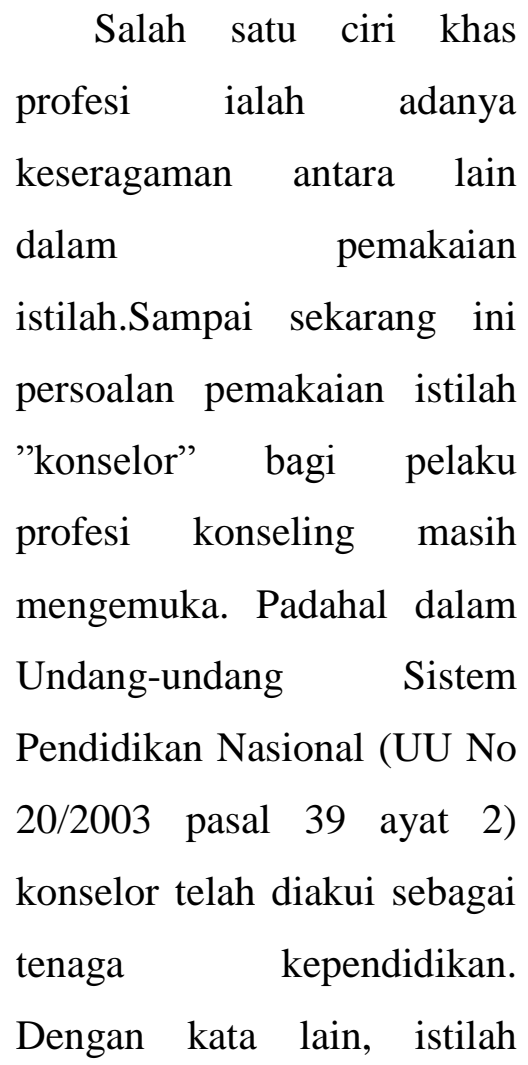


konselor memiliki legalitas hukum yang kuat. Di pihak lain, akhir-akhir ini banyak muncul istilah konselor seperti konselor AIDS, konselor Narkoba dan lainlain. Label konselor bisa dikatakan terdegradasi oleh kelatahan tersebut.

2. Miskonsepsi dan Malapraktik konseling di sekolah

Di samping kelemahan mutu layanan, tak jarang dijumpai praktik-praktik bantuan yang menyimpang dari pengertian dan asas profesi ini sebagai bentuk layanan kemanusiaan, bahkan kadang-kadang dijumpai terjadi malapraktek Munandir, 1996; Prayitno, 2004).

Beberapa miskonsepsi itu antara lain:

a. Layanan bimbingan dan konseling hanya bagi siswa yang bermasalah.

Sampai saat sekarang ini masih tumbuh asumsi di sekolah bahwa layanan bimbingan dan konseling itu hanya diperuntukkan kepada mereka yang bermasalah atau ekstrimnya "nakal". Siswa yang tidak bermasalah atau berkategori "baik-baik saja" tidak perlu diberikan layanan tersebut.

b. Konseling ditujukan untuk mendisiplinkan siswa.

Miskonsepsi ini hampirhampir sulit dihilangkan karena sedemikian rupa kesalahkaprahan praktik yang terjadi di sekolah lalu memunculkan "polisi sekolah" kepada para konselor. Layanan konseling seharusnya adalah sesuatu yang diperlukan, justru akhirnya menjadi sesuatu yang tidak disukai bahkan menakutkan.

c. Konseling adalah pemberian nasihat.

Padahal secara teoritik jelas bahwa tujuan konseling adalah 


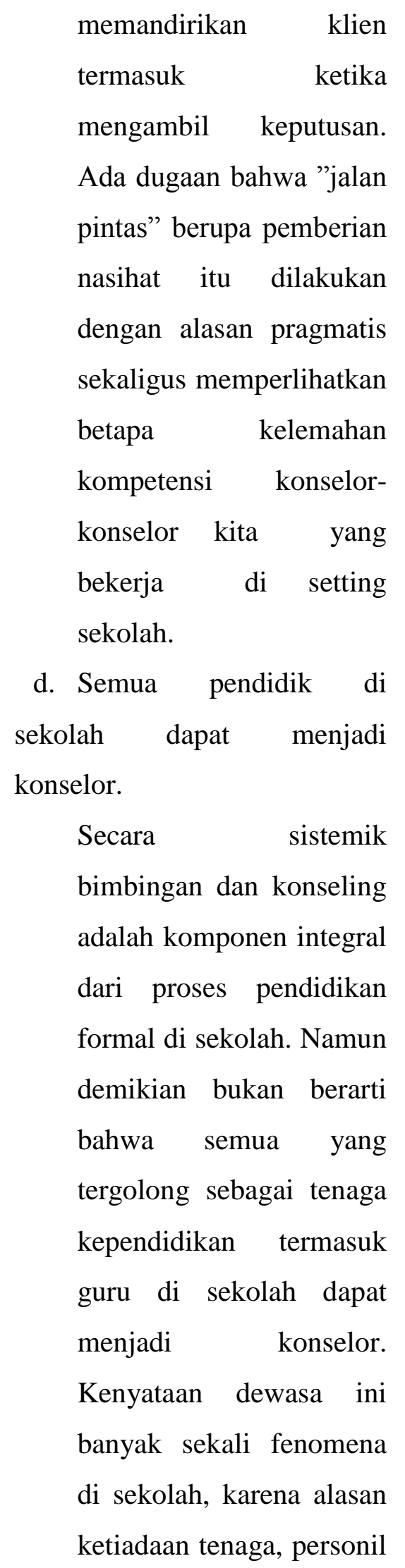

tenaga pendidik ditunjuk

sebagai pelaksana

pemberian layanan

konseling.

e. Konseling dilakukan

manakala diperlukan saja.

Anggapan keliru ini

masih saja terjadi di

sekolah. Semestinya

konseling adalah sesuatu

kegiatan yang terkelola

dan mengacu pada

tahapan menajemen yaitu

: perencanaan,

pelaksanaan, evaluasi dan

supervisi dan tindak

lanjut program.

3. Belum adanya pengakuan yang sehat dari masyarakat

Profesi konseling adalah tergolong helping profesion yang duduk sejajar dengan profesi pemberian bantuan lainnya. Namun dalam kenyataannya, profesi konseling dan sebutan konselor belum begitu melekat di hati masyarakat. Hal ini sebenarnya sudah dirasakan sejak lama, apalagi pada saat muncul perdebatan 
tentang tata cara kerja

konseling.

4. Masih terdapat pelaku profesi yang tidak bermandat.

Temuan survei dari lapangan (terutama di sekolah) menunjukkan bahwa masih cukup banyak pelaku profesi konseling yang belum memenuhi kualifikasi minimum. Lebih memprihatinkan lagi adalah munculnya fenomenafenomena seperti misalnya sarjana S1 non BK karena tidak punya job kemudian nimbrung bekerja sebagai Konselor tanpa disetarakan lebih dahulu, tahu-tahu ikutikutan menjadi konselor dengan berbekal modal kompetensi konseling yang sangat minim.

5. Penerapan Bimbingan Konseling yang belum meyakinkan.

Dibandingkan dengan profesi lainnya, harus diakui bahwa proses kredensialisasi/keyakinan profesi konseling kita belum mantap benar. Dalam beberapa hal seperti sertifikasi, akreditasi sudah berjalan, namun untuk lisensi konselor masih harus dipertanyakan.

Menjadi konselor profesional bukan lagi menjadi wacana di negeri ini dengan telah diselenggarakannya Pendidikan Profesi Konselor/PPK di Indonesia. Lepas dari polemik dan konflik kepentingan yang terjadi hingga saat ini, mestinya rintisan pendidikan profesi konselor/PPK ini disikapi secara positip oleh berbagai pihak yang terkait agar pada akhirnya akan mengutuhkan profesi konselor dengan ditandai adanya konselor yang tidak sekedar bersertifikasi saja namun juga berlisensi

3. Pelayanan Bimbingan Dan Konseling Dalam berbagai jalur

1. Jalur Pendidikan Informal

a. Pentingnya Bimbingan dan Konseling dalam Jalur Pendidikan Informal 
Perkembangan

individu tidak lepas dari pengaruh lingkungan, baik fisik, psikis maupun sosial. Perubahan yang terjadi dalam lingkungan dapat mempengaruhi gaya hidup (life style) warga masyarakat. Apabila perubahan yang terjadi itu sulit diprediksi, atau di luar jangkauan kemampuan, maka akan melahirkan kesenjangan perkembangan perilaku konseli, seperti terjadinya stagnasi (kemandegan)

perkembangan, masalahmasalah pribadi atau penyimpangan perilaku.

Iklim lingkungan
kehidupan yang kurang
sehat, seperti maraknya
tayangan pronografi di
televisi, VCD, dan internet,
penyalahgunaan alat
kontrasepsi, minuman
keras, obat-obatan
terlarang/norkoba, ketidak
harmonisan

kehidupan rumah tangga, dan dekadensi moral orang dewasa akan mempengaruhi

perkembangan individu. Untuk itu diperlukan pelayanan bimbingan dan konseling pada pendidikan informal.

Banyak permasalahan peserta didik yang disebabkan masalah otang tua, sehingga sering sekolah melibatkan keluarga dalam menyelesaikan permasalahan peserta didik. Upaya pelibatan orang tua dalam menyelesaikan masalah peserta didik ini menunjukkan pentingnya pelayanan bimbingan dan konseling pada jalur informal.Untuk itu pelayanan bimbingan dan konseling untuk jalur pendidikan informal sangat diperlukan.

b. Karakteristik Perkembangan Peserta Didik pada Jalur Informal 
Penyelenggaraan

pendidikan pada satuan

jalur pendidikan informal

adalah keluarga itu sendiri.

Pendidikan setara

nonformal yang dilakukan

pada pendidikan informal

adalah home schooling

contoh Pendidikan Anak

Usia Dini /PAUD. Dilihat

dari perkembangan peserta

didik, umumnya peserta

didik dalam home

schooling dalam tahap

perkembangan yang sama.

Beberapa masalah yang

menghambat

perkembangan peserta didik

adalah adanya degradasi

nilai adat istiadat yang

sering disebut tata susila

atau kesopanan terlihat

pada perilaku anak yang

akhir-akhir ini yang tidak

sopan terhadap orang tuaa,

guru, dan orang tua lainnya.

Degradasi nilai-nilai sosial

terlihat pada sikap

individualistis yang

berkembang di masyarakat,

dimana individu hanya mementingkan diri sendiri, dan enggan berbagi terhadap orang yang tidak berpunya. Kesakralan keluarga terlihat makin banyaknya kekrisuhan di dalam keluarga. Berbagai nilai tersebut jelas akan berpengaruh terhadap perkembangan peserta didik terutama pada satuan jalur pendidikan informal.

c. Tujuan Bimbingan dan

Konseling pada Jalur

Pendidikan Informal

Tujuan bimbingan dan konseling pada jalur pendidikan informal adalah membantu peserta didik mengenal dan menerima diri sendiri dan lingkungannya secara positif dan dinamis sesuai dengan peranan yang diinginkannya di masa depan. Banyaknya masalah yang terjadi pada peserta didik menjadi tantangan dalam keterlaksanaan bimbingan dan konseling. Prinsip-prinsip pelayanan 


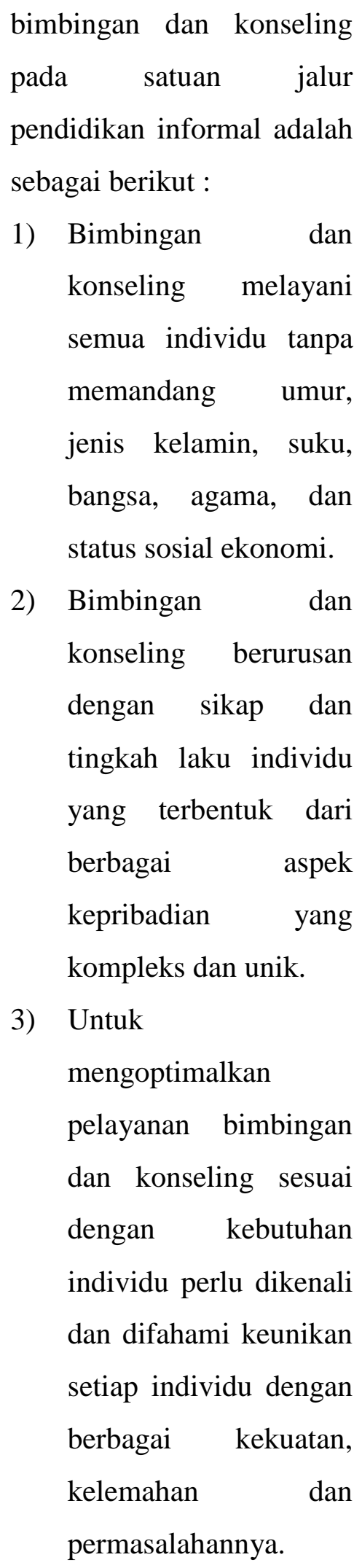

1) Bimbingan dan konseling melayani semua individu tanpa memandang umur, jenis kelamin, suku, bangsa, agama, dan status sosial ekonomi.

2) Bimbingan dan konseling berurusan dengan sikap dan tingkah laku individu yang terbentuk dari berbagai aspek kepribadian yang kompleks dan unik.

3) Untuk mengoptimalkan pelayanan bimbingan dan konseling sesuai dengan kebutuhan individu perlu dikenali dan difahami keunikan setiap individu dengan berbagai kekuatan, kelemahan dan permasalahannya.

4) Setiap aspek pola kepribadian yang kompleks seorang individu mengandung faktor-faktor yang secara potensial mengarah kepada sikap dan pola tingkah laku yang tidak seimbang.

5) Meskipun individu yang satu dan yang lainnya adalah serupa dalam berbagai hal, perbedaan individu harus difahami dan dipertimbangkan dalam rangka upaya yang bertujuan memberikan bantuan atau bimbingan kepada individu-individu tertentu, baik anakanak, remaja, maupun orang dewasa.

6) Bimbingan dan konseling berurusan dengan hal-hal yang menyangkut pengaruh kondisi mental/fisik individu terhadap penyesuaian dirinya di 
rumah, di sekolah, serta dalam kaitannya dengan kontak sosial dan pekerjaan, dan sebaliknya pengaruh kondisi lingkungan terhadap kondisi mental dan fisik individu.

7) Keadaan sosial, ekonomi, politik, dan budaya yang kurang menguntungkan merupakan salah satu faktor timbulnya masalah pada individu yang kesemuanya menjadi perhatian utama dari para konselor dalam mengentaskan masalah peserta didik (klien).

d. Pendekatan Bimbingan dan Konseling pada Satuan Jalur Pendidikan Informal Pelaksanaan layanan bimbingan dan konseling menggunakan layanan terpadu, artinya layanan bimbingan dan konseling dilaksanakan secara terpadu dengan seluruh kegiatan pendidikan. Pendekatan dalam bimbingan dan konseling yang cocok digunakan pada satuan jalur pendidikan informal adalah pendekatan yang berorientasi pada ketercapaian tugas perkembangan dan juga yang berorientasi pada masalah, artinya pelayanan bimbingan dan konseling lebih diorientasikan pada membantu peserta didik dalam mencapai tugas perkembangan dan membantu peserta didik dalam memecahkan masalah.

2. Dalam Satuan Jalur Pendidikan Formal

Pentingnya Bimbingan dan Konseling dalam Satuan Jalur Pendidikan Formal Dasar pemikiran penyelenggaraan pelayanan bimbingan dan konseling dalam satuan jalur pendidikan formal bukan semata-mata terletak adanya hukum 
(perundang-undangan) yang berlaku, tetapi yang lebih penting adalah menyangkut upaya memfasilitasi peserta didik agar mampu mengembangan potensi dirinya atau mencapai tugastugas perkembangannya yang mencakup aspek fisik, emosi, sosial, intelektual, dan moral spiritual. Peserta didik adalah individu yang sedang berada dalam proses berkembang yaitu berkembang ke arah kematangan atau kemandirian. Bimbingan dan konseling dalam satuan jalur pendidikan formal penting, mengingat bahwa perkembangan peserta didik pada masing-masing jenjang pendidikan akan berpengaruh pada perkembangan selanjutnya, misalnya perkembangan di TK/RA akan berpengaruh pada perkembangan selanjutnya, dimana perkembangan di SD/MISMP/MTs-SMA/MA/SMK, dan PT sangat ditentukan oleh bagaimana keberhasilan anak melampaui masa sekolahnya di TK/RA. Perkembangan di SD/MI dipengaruhi oleh perkembangan di TK/RA dan mempengaruhi perkembangan di SMP/MTs, SMA/MA/SMK dan PT, dan seterusnya.

\section{Jalur Pendidikan Nonformal}

a. Pentingnya Bimbingan dan Konseling dalam Jalur Pendidikan Nonformal Kenyataan di masyarakat tidak semua individu dapat mengikuti pendidikan formal di sekolah, banyak individu dengan segala keterbatasan baik fisik, ekonomi, atau sosial tidak mampu menyelesaikan dan/atau bersekolah pada jalur pendidikan formal dan bersekolah pada jalur pendidikan nonformal. Dilihat dari karakteristik warga belajarnya, usianya sangat bervariasi dan biasanya tidak sesuai dengan tahap perkembangannya. Dilihat dari waktu pelaksanaan dan 
proses

kegiatan

pembelajarannya juga lebih

fleksibel dibandingkan

pendidikan formal. Dengan

karakteristik

yang

demikian,

maka

kecenderungan masalah

yang dihadapi warga

belajar

pendidikan

nonformal lebih banyak

muncul. Dengan demikian

pelayanan bimbingan dan

konseling sangat

dibutuhkan pada satuan

jalur pendidikan formal.

b. Karakteristik

Perkembangan Warga
Belajar Jalur
Pendidikan
Nonformal

Peserta didik pada jalur pendidikan nonformal disebut warga belajar. Jenis pendidikan pada satuan jalur pendidikan nonformal diantaranya adalah Program Paket A, Program Paket B, dan Program Paket C. Program Paket A, Program Paket B, dan Program Paket
C disetarakan dengan pendidikan SD, SMP, dan SMA. Kenyataan di lapangan dalam Program Paket A, Program Paket B, dan Program Paket $\mathrm{C}$ warga belajarnya dengan usia bervariasi. Latar belakang pribadi, sosial, ekonomi, budaya warga belajarnyapun juga sangat bervariasi dan ada kecenderungan bahwa warga belajar yang sekolah pada pendidikan nonformal biasanya dilattarbelakangi dengan ada permasalahan sehingga warga belajar pindah atau bersekolah pada Program Paket A, Program Paket B, dan Program Paket C.

c. Tujuan Bimbingan dan Konseling pada Jalur Pendidikan Nonformal Bimbingan dan konseling juga bertujuan untuk membantu warga belajar agar memiliki kemampuan menginternalisasi nilai-nilai 
yang terkandung dalam

tugas-tugas perkembangan

yang harus dikuasainya.

Tujuan pelayanan

bimbingan dan konseling

mencakup:(a)

merencanakan kegiatan

penyelesaian studi,

perkembangan karir serta

kehidupannya dimasa yang

akan datang,

mengembangkan seluruh

potensi dan kekuatan yang

dimilikinya seoptimal

mungkin, (c) menyesuaikan

diri dengan lingkungan

pendidikan, lingkungan

masyarakat serta

lingkungan kerjanya, (d)

mengatasi hambatan dan

kesulitan yang dihadapi

dalam studi, penyesuaian

dengan lingkungan

pendidikan, masyarakat,

maupun lingkungan kerja

(Juntika, 2002).

\section{Bimbingan dan Konseling}

harus merebut kepercayaan

publik (public trust)

Untuk dapat melaksanakan

profesinya, seorang konselor harus memiliki visi dan misi secara luas dan mendalam dalam bidang profesinya sehingga dapat melakukan aksi pelayanan secara tepat dan akurat, disertai dedikasi yang tinggi untuk kepentingan pengguna (klien). Suatu profesi perlu didukung oleh (i) pelayanan yang tepat, (ii) pelaksana yang bermandat, dan (iii) pengakuan yang sehat dari berbagai pihak yang terkait. Ketiga hal tersebut dapat menjamin tumbuh suburnya profesi dan menjadikan profesi konseling menjadi profesi yang bermartabat.

Sebagai suatu profesi yang sedang berkembang, konseling harus merebut kepercayaan publik (public trust) melalui peningkatan mutu unjuk kerja konseling Hal ini dapat dilihat dalam Permendiknas no 27 tahun 2008 tentang kompetensi konselor. Public trust akan mempengaruhi konsep profesi dan memungkinkan anggota profesi berfungsi dengan caracara profesional. Public trust 
akan melanggengkan profesi konseling, karena dalam public trust terkandung keyakinan publik bahwa profesi dan para konselor berada dalam kondisi: (a) memiliki kompetensi dan keahlian yang disiapkan melalui pendidikan dan latihan khusus dalam standar kecakapan yang tinggi; (b) memiliki perangkat ketentuan yang mengatur perilaku profesional dan melindungi kesejahteraan publik; (c) anggota profesi konselor dimotivasi untuk melayani pengguna dan pihakpihak terkait dengan cara terbaik, dan memiliki komitmen untuk tidak mengutamakan kepentingan pribadi dan finansial.

Kepercayaan publik dapat menumbuhkan dan melanggengkan profesi Konselor karena beberapa hal: a). Kepercayaan publik berawal dari suatu persepsi tentang kompetensi, b). Kepercayaan publik diperkuat oleh persepsi terhadap kelompok profesional sebagai kelompok yang mampu mengatur dirinya sendiri dan diatur sesuai dengan kebutuhan masyarakat, c). Kepercayaan publik juga tumbuh karena adanya persepsi bahwa orangorang yang terlibat dalam suatu profesi konselor dimotivasi untuk melayani orang lain yang memerlukan bantuan, d) Profesi konseling tertantang untuk dapat mengembangkan

keprofesionalannya. Untuk mengembangkan profesi konseling ada tiga dimensi keprofesionalan, yaitu ilmu dan teknologi, pelayanan nyata kepada masyarakat, dan kode etik profesional.

Profesi konseling merupakan profesi yang bermartabat, maka perlu didukung oleh (a) pelayanan yang tepat dan bermanfaat bagi kemaslahatan kehidupan secara luas; (b) pelaksana yang bermandat, yaitu lulusan pendidikan profesi konselor, yang diharapkan benar-benar menjadi tenaga profesional handal yang layak memperoleh kualifikasi bermandat, baik 
dalam arti akademik, kompetensi, maupun posisi pekerjaannya. (c) pelayanan profesional konseling diakui secara sehat oleh pemerintah dan masyarakat. Dengan demikian diharapkan pengakuan secara terbuka baik oleh pemerintah dan masyarakat melalui pemanfaatan dan penghargaan yang tinggi atas profesi konselor.

Profesi konseling merupakan keahlian pelayanan pengembangan pribadi dan pemecahan masalah yang mementingkan pemenuhan kebutuhan dan kebahagiaan pengguna sesuai dengan martabat, nilai, profesi, dan keunikan individu berdasarkan kajian dan penerapan ilmu dan teknologi dengan acuan dasar ilmu pendidikan dan psikologi yang dikemas dalam kajiterapan konseling yang diwarnai oleh budaya pihak-pihak yang terkait

\section{Konsekuensi bagi prodi-prodi} di LPTK penyelenggarakan program studi bimbingan dan konseling

Telah ditegaskan melalui berbagai konvensi dan kongres nasional bahwa profesi konselor tidak lagi hanya digunakan di lingkungan sekolah saja namun juga digunakan juga pada setting kehidupan dan kelembagaan di luar sekolah. Tenaga konselor yang telah menyandang gelar profesi konselor dapat memberikan pelayanan Menumbuhkembangkan Karakter Konselor Profesional: Menuju profesi konseling di masyarakat luas, di dalam keluarga, perguruan tinggi, instansi dan lembaga resmi dan swasta, dunia usaha dan industri serta organisasi kemasyarakatan. Bagi konselor yang menempuh jalur pendidikan profesi PPK bisa membuka praktik mandiri (privat) untuk warga masyarakat luas sebagaimana layaknya dokter, apoteker, akuntan, pengacara, notaris, psikiater, psikolog, arsitek, bidan, dan praktik profesi lainnya. 
Dapat diprediksikan konseling bisa menjadi lahan karir yang menjanjikan seperti profesi lainnya yang sempat menjadi booming di negeri ini dan akan menjadi lahan baru yang "menggiurkan" bagi banyak penyelenggara lembaga pendidikan Konsekuensinya bagi prodi-prodi bimbingan dan konseling adalah menyiapkan lulusan secara lebih profesional sehingga mampu bersaing, mendapat tempat yang layak dan langsung berguna bagi masyarakat luas.

Berbagai pemikiran telah mendeskripsikan karakter konselor yang efektif, seorang konselor harus memenuhi beberapa persyaratan supaya dapat berhasil dalam melaksanakan profesinya yaitu : (1) Sikap hangat, dapat memahami, karakteristik individu sebagai kondisi fasilitatif yang dapat membantu perubahan yang terjadi pada pada klien; (2) memiliki rasa empati; (3) Kesadaran tentang diri dan pemahaman; (4)
Kesehatan psikologis yang baik; (5) Sensitivitas terhadap dan pemahaman faktor rasial, etnik dan budaya dalam diri sendiri dan orang lain;

Keterbukaaan; (7) Objektifitas; (8) Kompetensi; (9) Dapat dipercaya; dan (10) Sebagai seorang akademisi dan praktisi, pemikiran dan pengalamannya bertahun-tahun sehingga dapat dipercaya untuk diambil sebagai nilai-nilai pedoman.

Secara umum, para pakar BK tampaknya menyepakati bahwa pendidikan konselor tidak hanya pada tataran akademik dan intelektual saja (Prayitno, 2005) atau segi kognitif dan ketrampilan tetapi juga lebih mengutamakan segi afektif atau sikap pribadi konselor (Rosyidan,2002).

Perlu dipikirkan bagaimana rentang waktu yang cukup panjang tersebut (standar minimal 4 tahun) bisa digunakan untuk melihat adanya perubahan .performansi profesional seorang calon konselor. Kompetensi yang 
menjadi tujuan pencapaian mahasiswa tidak hanya dilihat melalui kompetensi akademik per mata kuliah saja tetapi bisa dilihat sebagai suatu proses pengayaan, pembinaan, dan pengembangan kepribadian mahasiswa setiap semester dan setiap tahunnya.

Jadi kurikulum bukan menghantarkan mahasiswa untuk menguasai materi sebanyak banyaknya tetapi mampu membekali mahasiswa mengembangkan dirinya hingga kemudian secara mandiri menunjukkan kinerja profesional sebagai calon konselor.

\section{Kebutuhan Pasar Global akan}

\section{Layanan Bimbingan dan}

\section{Konseling}

Masyarakat yang tiap hari disibukkan dengan rutinitas pekerjaan dan kariernya. Bekerja dibawah tekanan dan kecemasan akan kesuksesan dalam kariernya. Seringkali pula banyak diantara mereka yang melupakan bahwasannya dirumah mereka mempunyai anak-anak dan keluarga yang membutuhkan perhatian lebih dan kasih sayang. Kecenderungan kriminalitas meningkat dan kenakalan remaja serta perbuatan-perbuatan yang melampaui norma-norma sosial semakin subur. Di sisi lain, masyarakat perkotaan tak bisa lepas dari fenomena sosial kemiskinan, dan masyarakat yang terpinggirkan. Sikap individualitas muncul. Acuh tak acuh terhadap sesama kerabatnya, yang penting uang dan barang. Mata, pikiran serta agama telah fokus pada bagaimana pencapaian materi yang sebanyak-banyak.

Begitulah dunia globalisasi saat ini, tanpa batas geografi lagi globalisasi telah menjangkau seluruh cakupan dunia. Negaranegara yang kultural lambat laun menjadi multi kultural. Akan tetapi, manusia sebagai bagian dari masyarakat dan lingkungan sosial sertai sebagai semestinya mempunyai dimensi individualitas, sosial, moral dan agama. Tampaknya telah lupa pada tujuan hidupnya sendiri dan 
fitrah lahiriah. Oleh karena itu, keberadaan konselor, psikolog dan pskiater sesungguhnya sangat dibutuhkan dan mempunyai peranan penting di dalam masyarakat industri seperti sekarang ini. Kehadiran konselor sepertinya menjawab tantangan zaman dan seiring dengan pesatnya kemajuan pasar global. Semakin terbuka dan semakin jauh dekade per dekade, individu akan membutuhkan bimbingan hidup dan layanan konseling lainnya. Ini membuka peluang, bahwasannya saat ini dan ke depan, kebutuhan akan profesi Bimbingan dan Konseling tidak hanya dapat diselenggarakan di sekolah-sekolah dan institusi pendidikan, tetapi juga harus pula diselenggarakan di bidangbidang lain seperti industri dan klinis.

\section{Konselor "Multi Skill"}

Jika seorang calon konselor cukup puas dengan kemampuan dan keahlian serta kompetensi yang sudah dikuasai secara benar dibangku perkuliahan saja tanpa membekali dengan kemampuan (Skill) lain. Hal ini, jelas akan menjadi pertanyaan besar, "apakah bisa menembus ketatnya persaingan dunia profesi di pasar global?", jawabannya sangat sulit.

Salah satu kemampuan yang harus dikuasai oleh calon konselor adalah kemampuan berbahasa asing terutama bahasa inggris. Dalam pasar kerja dewasa ini yang sangat kompetitif, perusahaan beroperasi pada tingkat global, ketrampilan bahasa Inggris dapat membuat perbedaan antara mendapatkan suatu pekerjaan yang baik dan tidak mendapatkan pekerjaan sama sekali. Calon pekerja profesional harus dapat "melek" teknologi dan dapat menjalankan program-program komputer terutama yang dibutuhkan dalam dunia kerja sesuai dengan bidang kerjanya. Kemampuan lain yaitu "soft skill" meliputi dapat bekerja secara tim dan organisatoris, mempunyai kemampuan managerial (kepemimpinan) 
yang baik, interaksi sosial, komunikasi antar pribadi yang efektif, kemampuan berbicara dimuka umum, dan lobbying. Mahasiswa atau calon pekerja professional yang tidak mempunyai "soft skills" tidak akan dapat bertahan lama di dalam dunia kerja. Karena dunia kerja penuh dengan tantangan dan tekanan.

Pendapat pakar hal yang diaplikasikan ke dalam profesi konselor sebagai berikut:

a. Speaking Skill (Keterampilan Menyampaikan

Gagasan/Berbicara), setiap konselor diharapkan memiliki keterampilan berbicara, bagaimana mengungkapkan gagasan dan pendapat dengan baik, serta memberikan pengarahan dengan baik. Konselor diharapkan dapat berkomunikasi secara efektif. Untuk itu diperlukan penguasaan tidak hanya keterampilan berkomunikasi secara verbal, tetapi juga secara non verbal. b. Thinking Skill (Keterampilan Berpikir/Intelektual)

Kemampuan untuk mendayagunakan otak dengan optimal. Berpikir merupakan sebuah proses memahami realitas dalam rangka mengambil keputusan (decision making), memecahkan masalah (problem solving), untuk itu diperlukan kemampuan berpikir kreatif, sistematis, integratif, logis/rasional, jernih, dan kritis.

c. Interpersonal Skill (Keterampilan Menjaga Hubungan Antarpribadi) Agar komunikasi berjalan efektif dibutuhkan hubungan interpersonal yang baik. Taylor et. al (dalam Rakhmat 2002) menyatakan bahwa banyak penyebab dari rintangan komunikasi berakibat kecil saja bila ada hubungan baik di antara komunikan. Sebaliknya, pesan yang paling jelas, paling tegas, dan paling cermat tidak dapat 
menghindari kegagalan, jika terjadi hubungan jelek.

d. Network Skill (Keterampilan Mengembangkan,

Membangun Jaringan atau

Meluaskan Hubungan Kerja)

Konselor diharapkan berjiwa

kosmopolit, yaitu mampu

membangun kontak dengan

dunia luar. Dengan

membangun jaringan ke luar,

maka akan bertambah

wawasan, pandangan dan

pola pikir. Para konselor akan

banyak terbantu dalam

menyelesaikan berbagai

persoalan tertentu dengan

adanya informasi-informasi

dari luar.

e. Growth (Keterampilan Mengembangkan Diri) Para konselor diharapkan, secara sadar, mau dan mampu untuk secara terus menerus mengembangkan diri ke arah yang lebih baik mampu memperlihatkan kemampuan diri secara optimal, dan mampu mendorong diri sendiri untuk mengembangkan kapasitas prestasi secara optimal.

f. Dicipline (Disiplin) Ketaatan dan kepatuhan serta kerelaan dalam menjalankan tugas sesuai dengan aturan yang berlaku. Setiap konselor secara sadar dan sukarela harus taat pada berbagai ketentuan yang berlaku dan memenuhi standar nilai atau norma yang telah ditetapkan baik yang berlaku di lingkup organisasi, masyarakat, dan agama. Perasaan memiliki dan kecintaan terhadap pekerjaan harus dikembangkan dan menjadi komitmen dalam diri setiap konselor, sehingga akan selalu berusaha untuk memberikan yang terbaik dalam menjalankan profesinya.

\section{Menjadi}

Konselor

\section{berkompetensi}

Mahasiswa program studi Bimbingan dan Konseling sebetulnya disiapkan menjadi konselor sekolah. Pemerintah pada tahun ini mulai 
memberlakukan manajemen moderen, dengan adanya Permendiknas No 27 Tahun 2008 tentang Standart kwalifikasi Akademik dan Kompetensi Konselor serta Permenpan No 16 tahun 2009 tentang Penilaian Kinerja Guru , juga bagi Guru Bimbingan Konseling.

\section{Konsultan Pendidikan}

Seorang konselor, dibekali dengan ilmu-ilmu mengenai pendidikan dan perkembangan peserta didik. Sehingga bukan hal yang baru lagi, jika seorang konselor dapat pula menjadi seorang konsultan pendidikan baik secara privat maupun untuk layanan pendidikan di sekolahsekolah.

Paradigma pendidikan adalah investasi masa depan, masih sangat melekat dipikiran masyarakat modern. Kehadiran dan keberadaan seorang konsultan pendidikan dibutuhkan masyarakat untuk membantu memberikan pertimbangan-pertimbangan yang obyektif bagi masa depen investasi mereka. Diposisi ini. Seorang lulusan Bimbingan dan Konseling cukup diunggulkan. Karena dalam masa studinya, mahasiswa bimbingan dan konseling banyak mempelajari mengenai pendidikan dan perkembangan serta diharuskan menguasai kompetensinya. Hal ini jelas berbeda dengan lulusan pendidikan bidang studi tertentu, yang tidak berkaitan langsung dengan dunia pendidikan.

Di lain pihak, sekolah sebagai institusi pendidikan juga membutuhkan pertimbanganpertimbangan khusus utamanya dari seorang yang ahli. Untuk menentukan arah dan pencapaian kesuksesan belajar peserta didiknya serta dinamika pendidikan yang semakin kompleks. Akan tetapi, Konsultan pendidikan masih jarang ditemui di tengah-tengah masyarakat.

10. Konselor Membuka Praktek Layanan Konseling Untuk Umum 
Kalau memang kita cermati seharusnya kebutuhan masyarakat akan konselor di era pasar global menunjukkan angka yang cukup tinggi. Berbagai macam kasus, mulai dari yang bersifat psikologis hingga kekerasan fisik (seperti KDRT) mewarnai dinamika kehidupan masyarakat dewasa ini. Tidak hanya di dunia pendidikan saja, seorang konselor profesional dapat membuka prakteknya. Bidangbidang lain seperti masalah perkembangan anak dan remaja, keluarga, karier, pernikahan membutuhkan perhatian yang cukup besar.

Konselor yang berkeahlian dan berkompetensi lebih mempunyai kesempatan yang masih cukup lebar dalam mengembangkan praktek layanan konseling untuk umum. Beberapa contoh, praktek layanan konseling yang diselenggarakan untuk umum (dari sumber internet)

$$
\text { Elly dalam situsnya }
$$
www.konselingkeluarga.com membuka layanan konseling professional (konseling keluarga) melalui email, tatap muka, dan vip. Keterangan Elly yang penulis ambil dari websitenya ,Saya sebagai Konselor Profesional memiliki telinga untuk mendengar persoalan Anda, memiliki kepekaan hati untuk menuntun Anda melihat dengan jernih permasalahan yang Anda hadapi dengan disertai pembekalan nyata dari pergumulan kehidupan serta pembelajaran ilmu konseling dan psikologi dan pengayaan dari praktek konseling. Telah berkarier sebagai praktisi keuangan selama 15 tahun dan kini menekuni ilmu psikologi dan konseling. Memiliki hobby membaca memperkaya khasanah batin, melukis menuangkan keindahan alam ciptaan Tuhan ke atas kanvas dan menulis mencurahkan pikiran yang dapat menjadi inspirasi bagi sesama.

Semua upaya tersebut akan berhasil nyata jika setiap Calon 
Konselor dan guru Konselor Sekolah terus berusaha meningkatkan kompetensi baik melalui diklat maupun belajar mandiri. Menjadi Konselor profesional bukanlah keturunan nenek moyang, melainkan diperoleh melalui proses belajar. Lakukan apa yang anda pikirkan dan tulis yang anda lakukan. Menuntut berlebihan sebelum berbuat apa-apa sama artinya tidak mau berbuat.

Yakinlah anda bisa sukses memberi layanan dengan inovasi anda. Selamat berjuang mencari jati diri positif di tengah keterbatas. Sukses untuk Calon Konselor dan Konselor Sekolah. Saya cinta Konselor, saya memajukan Konselor, dan saya bangga menjadi Konselor.

\section{Daftar Pustaka}

Ditjen Dikti. 2007. Standar

Kompetensi Konselor. Bandung : PB ABKIN

Permendiknas Nomor 27 Tahun 2008 tentang Standar Kualifikasi Akademik dan Kompetensi Konselor.

Permenegpan \& RB Nomor 16

Tahun 2009 tentang Jabatan
Fungsional Guru dan Angka Kreditnya

Prayitno. 2004. Pengembangan Profesional Guru Pembimbing (Bahan Diklat), Jakarta: PPPG Keguruan Jakarta

Mungin Eddy Wibowo. 2011. Profesionalisasi Bimbingan dan Konseling (bahan Diklat). Jakarta Pusat Pengembangan Dan Pemberdayaan Pendidik Dan Tenaga Kependidikan Pendidikan Jasmani Dan Bimbingan Konseling

Rudi Mulyatiningsih. 2011. Profil Kompetensi dan Kinerja Guru BK Profesionaldan Upaya Mewujudkannya (Bahan Diklat). Jakarta: Pusat Pengembangan Dan Pemberdayaan Pendidik Dan Tenaga Kependidikan Pendidikan Jasmani Dan Bimbingan Konseling

Naharus Surur. 2011. Profil Kompetensi Dan Kinerja Profesional Guru Bimbingan Dan Konseling (BK) Serta Upaya Mewujudkannya (Bahan Diklat). Jakarta: Pusat Pengembangan Dan Pemberdayaan Pendidik Dan Tenaga Kependidikan Pendidikan Jasmani Dan Bimbingan Konseling 